\title{
DETERMINANTS OF HOUSEHOLD FOOD SECURITY OF PADDY FARMERS IN BAT- TICALOA DISTRICT, SRI LANKA
}

\author{
Krishnal Thirumarpan* \\ Department of Agricultural Economics, Faculty of Agriculture, \\ Eastern University, Sri Lanka
}

Accepted: $20^{\text {th }}$ February 2015

\begin{abstract}
Declining crop productivity and farm income in Sri Lanka forced rural households to adopt various coping mechanisms to mitigate the food insecurity status. This study aimed to analyze the paddy farmer's coping behaviors, food security status and the determinants of food security. Food security was measured using coping strategies index and multinomial logistic regression was done to analyze the determinants of food security. Results revealed that, mean monthly income of the household was Rs. 13, 104.33. Almost all the households adopted various coping mechanisms. $30 \%$ of households were in food insecure condition. Multinomial logistic regression results revealed that family size, education level of the head of the household and total monthly income significantly influence the food security status. When household monthly income increases, the odds ratio to be food secure and moderately food secure increases by one. Considering the diversity of coping strategies employed in the study area, policy instruments should be designed to improve the income level coupled with proper education and thereby to improve the food security status among rural household in Batticaloa district.
\end{abstract}

Key words: Coping behaviors, food security, Multinomial Logistic regression

\section{INTRODUCTION}

. Sri Lanka's preferred staple food is rice and it provides an average of $45 \%$ total calorie and $40 \%$ total protein requirement of an average Sri Lankan and plays a significant role in stabilizing food security in the country (Department of Agriculture, 2013). It is one of the major staples, which can provide a nation's population with the nationally required food security minimum of 2,400 calories per person per day (FAO, 2000). The crop is commonly consumed even as a food crop for household food security. The major substitute to rice is wheat flour which is only second to rice in Sri Lankan diet in terms of providing major nutrients. It is important to note that meat, eggs, milk and fish in fulfilling the protein needs of the consumers. If the same food preferences and the composition of the diet continues, increased availability and accessibility to rice, wheat flour and fish appears to be the shortest way to improve food and nutritional security in Sri Lanka, particularly in the long run (Samaratunga, 2011). Besides demand for rice is growing, due to increase in population. From the foregoing it is clear that much effort is needed to secure stable paddy harvests and food security.

Today, food security has become a fundamental problem faced by the mankind in the world. Food security is a flexible concept as reflected in many attempts at definition in research and policy usage. The concept of food security addresses people's risks of not having access to the required food (Von Braun et al., 1992). Coping strategies are set and recognized based on the culture and traditional atmosphere in order to overcome the critical effects of food insecurity. Thus, the coping strategies are the means that people use in order to maintain their livelihoods during the stress time such as famine, drought, flood, etc. (Abdelrazig and Ahmed, 2006). Thus, there are several coping strategies that households

\footnotetext{
*Corresponding author: skrish_16@yahoo.com
} 


\section{KRISHNAL THIRUMARPAN:DETERMINANTS OF HOUSEHOLD FOOD SECURITY}

adopt when they face the dilemma of food insecurity.

This study analyses status of food security of paddy farmers in Batticaloa district using coping strategies index.

This study focuses on the following specific objectives

To study the socio economic status of paddy farmers in Batticaloa district

To analyse the farm household's coping strategies during food shortage

To identify the status of food security of paddy farmers.

To identify the determinants of food security of paddy farmers

\section{METHODOLOGY}

\section{Study site and data collection}

The total size of paddy land in the Batticaloa district amount to 58,937 hectare which accounts for $14 \%$ of the national paddy extent and stands fourth following Anuraduhpura (19\%), Kurunegala (18\%) and Ampara (16\%) (WFP, 2009). More than three-fourth of the paddy land is located in five DS divisions namely Porathivu Pattu, Manmunai West, Eravurpattu, and Korelapattu and Korralai Patu North. The study was carried out in three selected Divisional Secretariat (D. S.) divisions in Batticaloa district viz. Manmunai west, Korelapattu and Eravurpattu D.S. divisions. In these three D. S. divisions, ten Grama Niladhari divisions were selected and from each Grama Niladhari division five paddy farming families were selected randomly. Altogether 150 samples were collected from the district.

Household sample surveys generated both qualitative and quantitative data pertaining to social, demographic and economic characteristics. Specific questions were asked on the measures taken by households for smoothening food consumption pattern in case of food shortages.

\section{Data analysis}

Socio economic status of the household and perception of coping strategies were presented using frequencies and descriptive statistics. Status of food insecurity was calculated using the Coping Strategies Index in this study. According to FAO (1996), Food security, at the individual, household, national, regional and global levels (is achieved) when all people, at all times, have physical and economic access to sufficient, safe and nutritious food to meet their dietary needs and food preferences for an active and healthy life". Coping Strategies Index was constructed on the basis of asking questions about locally applicable coping behaviors, Maxwell et al. (1999) tested the Coping Strategies Index against various benchmarks of food security, and found significant correlation with other indicators of food security including dietary intake (kilocalories per adult equivalent per day), per capita expenditure and the proportion of expenditure on food, and various anthropometric measures in one specific case. A series of questions about how households manage to cope with a shortfall in food for consumption results in a simple numeric score. The frequency of a specific behavior was weighted by the perceived severity of that behavior, and this was summed up across all the behaviors in the list that were derived. The Coping Strategies Index tool relies on counting up coping strategies that are not equal in severity. Different strategies were 'weighted' and then multiplied by a weight that reflects their severity before being added together. The severity of coping strategies is, to some extent, a matter of perception. While not eating for a whole day or sending the household members to beg undoubtedly constitute severe coping behaviors in nearly any culture, some strategies would be looked on as perfectly normal behavior in some places and in some other places may be practiced in the most extreme circumstances. To establish the severity of each strategy or behavior first strategies were grouped into categories that are of roughly the same level of severity. Then they were categorized into four different categories and the weights were assigned accordingly.

Very severe-4

Severe-3

Moderate-2

Least severe-1 
Finally for each and every coping behavior the frequency was multiplied by its severity score and all were added to get the total household score which was used to check the food security status of the household. This index resulted in a score that reflects current and perceived future food security status. Based on this scores they were divided into Food secure, Moderately Food secure and Food insecure status. Higher score indicates a greater level of coping, and hence increased food insecurity.

The data were analyzed in two stages: stage one calculates the household food security status; and stage two was an analysis of the determinants of food security.

Households were classified according to three mutually exclusive states of food security: food secure $(S=0)$, Moderately food secure $(S=1)$ and food insecure $(S=2)$. The empirical analysis uses multinomial logistic regression to compare the probability of two of the outcomes to the probability of the third (omitted) outcome, in this case $\mathrm{S}=2$. Multinomial logistic regression was used to predict categorical placement on a dependent variable based on multiple independent variables and that allows for more than two categories of the dependent or outcome variable.

The model estimates the following two equations:

$$
\begin{gathered}
\operatorname{Ln}\left[\operatorname{Prob}\left(\mathrm{S}_{\mathrm{i}}=1\right) / \operatorname{Prob}\left(\mathrm{S}_{\mathrm{i}}=0\right)\right]=\alpha_{0}+\alpha_{1} \mathrm{X}_{\mathrm{i}} \\
\operatorname{Ln}\left[\operatorname{Prob}\left(\mathrm{S}_{\mathrm{i}}=2\right) / \operatorname{Prob}\left(\mathrm{S}_{\mathrm{i}}=0\right)\right]=\beta_{0}+\beta_{1} \mathrm{X}_{\mathrm{i}}
\end{gathered}
$$

Where $X_{i}$ is a vector of household socio economic characteristics.

\section{RESULTS AND DISCUSSION}

\section{Socio economic characteristics}

Average family size was 4.3 with the minimum of 2 and maximum of 7 . Mean age of the head of the household was about 48 years (Table 1). Majority (73\%) of the respondents were Tamils followed by Muslims. Majority $(85.3 \%)$ of the respondents was of Hindu religion, $8.7 \%$ of them were Islam and the rest were in other religion.

Almost all of the head of the household practiced paddy farming as their primary occupation and $20 \%$ involved in fishing as secondary

\begin{tabular}{|c|c|c|c|}
\hline Variables & Minimum & Maximum & Mean \\
\hline Family size (Number) & 2 & 7 & $4.30(1.57)$ \\
\hline Age of the Head of the household (Years) & 27.00 & 73.00 & $47.89(12.08)$ \\
\hline Monthly household average income (Sri Lankan & 1350 & 40000 & $13104.33(8597.21)$ \\
\hline Rupees) & & & \\
\hline
\end{tabular}

Table 1: Socio economic profile of paddy farmers

The household heads were of diverse levels of education. Forty four percentage of the head of the household had the education level upto primary and twenty six percentage of the paddy farmers had the education level of post secondary, while $1.3 \%$ were uneducated (Table 2). The number of years spent in formal education is one of the important determinants of increased household food production and adoption of new behaviours. Further, education catalyses the process of information flow and leads persons to explore as wide as possible, different pathways of getting infor- mation about agriculture and food security (Ersado, 2001).

Table 2: Education level of the head of the household

\begin{tabular}{lc}
\hline Level of Education & Frequency \\
\hline None & 2 \\
Primary & 66 \\
Secondary & 43 \\
Post secondary & 39 \\
Total & 150 \\
\hline
\end{tabular}


earning and the rest involved in small scale business, homegardening etc. as secondary income source. Mean monthly income of the household was Rs. 13, 104.33 with the minimum of Rs. 1350. 00.

\section{Food security status of paddy farmers in Batticaloa}

The frequency of the coping behaviors and the severity of the strategies were combined in a single score, the Coping Strategies Index, which was the indicator of the household's food security status. About $48.7 \%$ of the households were in moderate food security condition, $21.3 \%$ of the households in food secure condition and the rest were in food insecure condition (Table 3). A household where no one eats for an entire day is clearly more food insecure than one where people have simply switched from consuming rice to cassava. Among the three D. S. divisions in Manmunai West had the highest food insecure households (47\%) followed by Korelapattu and Eravurpattu divisions.

Different coping strategies used by paddy farmers in Batticaloa district and their frequencies

Table 3: Food security status of the paddy farmers

\begin{tabular}{clc}
\hline Food security status & Frequency & Percent \\
\hline Food secure & 32 & 21.3 \\
Moderately secure & 73 & 48.7 \\
Food Insecure & 45 & 30.0 \\
Total & 150 & 100.0 \\
\hline
\end{tabular}

During periods of food shortages and restricted access to food, households changed their daily behaviour to adapt to these critical problems. Almost all of the sampled households indicated that they had employed these coping strategies as short-term measures during times of food shortages. With the exception of consumption of seed stocks held for next season, most of these coping strategies were usually reversible.

The study showed that households employed following coping strategies to mitigate food shortages : a Eating foods that are less preferred

Vast majority of the respondents in all income groups reported long-term trends toward consuming foods that were less preferred and less expensive. Those foods were inadequate for living healthy and active lives. Among them $83.3 \%$ of the respondents used this strategy pretty often and $10 \%$ of them used once in a while. $3.3 \%$ of the households never used this strategy.

b. Borrowing food, or rely on help from a friend or relative

Borrowing either food or money was a commonly-mentioned practice and $68 \%$ of the respondents reported this strategy(table 4). Borrowing food, or rely on help from friends or relatives is indicative of strong social networks among rural households (Majake, 2005; Monde, 2003).

\section{c. Purchase food on credit}

$94.7 \%$ of the respondents purchased food on credit from their relations or neighbors during crisis situations. Among these $4.7 \%$ of the respondents employed this strategy hardly at all and $16.7 \%$ used pretty often. Purchasing food on credit is a short-term coping strategy with the potential of putting a household in a more vulnerable position in the long-term (Majake, 2005; Maxwell et al., 2003).

d. Gather wild food, hunt orr harvest immature crops

Majority (92\%) of the respondents stated that they gathered wild food such as yams, Amaranthus or harvested immature crops during food crisis situations. A previous study argued that the consumption of wild food as a coping mechanism to address food shortages may be associated with diseases and other health problems as in the case of Ethiopia (Jenny and Egal, 2002). Nonetheless, wild foods collected by farm households represent a normal strategy to mitigate the effects of food insecurity in North Sudan (USAID, 2010). Studies from other Southern African countries (Zambia, Mozambique, Zimbabwe and Ma- 
lawi) illustrates that, due to a high rise in prices of staple foods, prolonged droughts and poor harvests, dependence on wild foods has increased to combat food insecurity (World Food Programme, 2009).

e. Consume seed stock held for next season About $87.3 \%$ of the paddy farmers consumed seed stock held for next season. Majority of the farmers consumed the rice that was kept for next season, and $49.3 \%$ of the households used this strategy less than one time per week.

f. Sending household members to eat elsewhere

Only $7.3 \%$ of the households adopted this strategy and they sent their family members to their relation's houses or to neighbors.

g. Send household members to beg and skip entire days without eating

Since these two are cruel strategies none of the households adopted these strategies.

\section{h. Limiting portion size at meal times.}

Limiting the quantity of food served to an individual was practiced in the majority $(94.7 \%)$ of households in the survey. Nevertheless, cutting back the amount of food that each person in the household gets was the second most common coping strategy, and in terms of severity, it is roughly equivalent to eating foods that are less preferred. If more than a modest reduction of food is involved, most respondents reported that they would skip meals. The manner in which limiting portion size, varied widely among households.

i. Feed working members of household at the expense of non -working members

In case of food shortage situations, the household members who were working were fed at the expense of members who were not working. Only very few (14\%) respondents followed this coping behavior. Among them, majority used this strategy less than 1 time/week

j. Ration the money you have and buy prepared food

$48 \%$ of the paddy farmers never used this coping behavior, and. $22.7 \%$ adopted this strategy once in a while and $20.7 \%$ used this strategy less than one time per week.

$\mathrm{k}$. Reduce number of meals consumed in a day $68.3 \%$ of the respondents used this behavior. Amid this majority used this strategy less than one time per week.

Table 4: Frequency application of coping strategies

\begin{tabular}{|c|c|c|c|c|c|}
\hline \multirow[t]{2}{*}{ Coping Strategies } & \multicolumn{5}{|c|}{ Relative frequency of households using the strategy } \\
\hline & $\begin{array}{l}\text { All the time? } \\
\text { Everyday }\end{array}$ & $\begin{array}{l}\text { Pretty often? } \\
\text { 3-6/week }\end{array}$ & $\begin{array}{l}\text { Once in a while? } \\
1-2 / \text { week }\end{array}$ & $\begin{array}{l}\text { Hardly at all? } \\
<1 / \text { week }\end{array}$ & Never \\
\hline $\begin{array}{l}\text { a. Rely on less preferred and less expensive } \\
\text { foods? }\end{array}$ & 1 & 125 & 15 & 4 & 5 \\
\hline $\begin{array}{l}\text { b. Borrow food, or rely on help from a friend } \\
\text { or relative? }\end{array}$ & 0 & 25 & 52 & 25 & 48 \\
\hline c. Purchase food on credit? & 2 & 111 & 22 & 7 & 8 \\
\hline $\begin{array}{l}\text { d. Gather wild food, hunt, or harvest immature } \\
\text { crops? }\end{array}$ & 4 & 67 & 32 & 35 & 12 \\
\hline e. Consume seed stock held for next season? & 0 & 49 & 74 & 8 & 19 \\
\hline f. Send household members to eat elsewhere? & 0 & 0 & 3 & 8 & 139 \\
\hline g. Send household members to beg? & 0 & 0 & 0 & 0 & 150 \\
\hline h. Limit potion size at meal times & 26 & 69 & 17 & 30 & 8 \\
\hline $\begin{array}{l}\text { i. Feed working members of } \mathrm{HH} \text { at the ex- } \\
\text { pense of non -working members? }\end{array}$ & 0 & 1 & 4 & 16 & 129 \\
\hline $\begin{array}{l}\text { j. Ration the money you have and buy pre- } \\
\text { pared food? }\end{array}$ & 6 & 7 & 34 & 31 & 72 \\
\hline $\begin{array}{l}\text { k. Reduce number of meals consumed in a } \\
\text { day? }\end{array}$ & 0 & 3 & 39 & 60 & 48 \\
\hline 1. Skip entire days without eating? & 0 & 0 & 0 & 0 & 150 \\
\hline
\end{tabular}




\section{Determinants of food security}

Nagelkerke's $\mathrm{R}^{2}$ of 0.426 indicated a moderately strong relationship between predictors and prediction. Model chi square was 70.09 significant at 0.01 showed significant relationship between dependent and independent variables. Family size, education level of the head of the household and total monthly income significantly influences the food security status of the household of paddy farmers. One unit increase in family size decreases the odds ratio to be food secure rather than food insecure by 0.66 . Odds ratio is the ratio of the odds of an event occurring in one group to the odds of it occurring in another group (Grimes and Schulz, 2008). Bashir et al., (2012) found similar observation in his study where, an increase of an additional family member decreases the chances of a household to become food secure by $31 \%$. . In India, Sindhu et al., (2008) found that an increase in one family member increases the chances of a household becoming food insecure by $49 \%$. A study by Babatunde et al., (2007) concluded that larger household sizes are more likely to be food insecure than smaller size households.

While the odds ratio for someone in Manmunai West divisional Secretariat division to be food secure rather than in food insecure are 0.05 times the odds for someone in other Divisional Secretariat divisions. When household monthly income increases, the odds ratio to be food secure and moderately food secure increases by 1.0. This can also be explained as an increase of Rs 1000 in monthly income of a household increases the chances to be food secure by one time. This can be done by converting the value of the coefficient into Odds ratio for an increase of Rs 1000 as; exp ${ }^{0.0001 * 1000}$ $=1.105$. Bashir et al., (2012) found that an increase of Rs. 1000 increases the chances of rural households to become food secure by 5\%. Similarly, using categorical variables, Bashir et al., (2010) also found a positive impact of income on food security. For India, Sindhu et al., (2008)

using the same analytical technique for India, found that the chances of food security increases by $30 \%$ with an increase of 1000 Indian Rupees in monthly incomes.

Table 5: Determinants of food security among the paddy farmers in Batticaloa district

\begin{tabular}{|c|c|c|c|c|}
\hline Variables & Category & Coefficient (Standard Error) & $\mathbf{B}$ & P value \\
\hline \multicolumn{5}{|l|}{ Food Secure } \\
\hline Family size & & $0.66(0.21)$ & -0.41 & $0.055^{*}$ \\
\hline Age of $\mathrm{HH}$ Head & & $1.02(0.03)$ & 0.23 & 0.406 \\
\hline Education level of $\mathrm{HH}$ head & & $0.64(0.18)$ & -0.44 & $0.012^{*}$ \\
\hline Monthly HH income & & $1.0(0.0)$ & 0.00 & $0.001 * * *$ \\
\hline \multirow[t]{3}{*}{ D. S. Divisions } & Manmunai West & $12.57(1.29)$ & 2.53 & $0.05^{*}$ \\
\hline & Eravurpattu & $27.74(1.15)$ & 3.32 & $0.004 * * *$ \\
\hline & Korelapattu & & $0^{\mathrm{b}}$ & \\
\hline \multirow[t]{3}{*}{ Religion } & Hindu & $9.045 \mathrm{E} 13(1234.08)$ & 32.13 & 0.97 \\
\hline & Islam & 4.917E13(1234.08) & 31.526 & 0.98 \\
\hline & Other religion & & $0^{\mathrm{b}}$ & \\
\hline Constant & & & -16.13 & \\
\hline \multicolumn{5}{|l|}{ Moderately Food secure } \\
\hline Family size & & $0.79(0.18)$ & -0.23 & 0.20 \\
\hline Age of $\mathrm{HH}$ Head & & $0.99(0.02)$ & -0.003 & 0.89 \\
\hline Education level of $\mathrm{HH}$ head & & $0.72(0.14)$ & -0.33 & $0.015^{*}$ \\
\hline Monthly HH income & & $1.00(0.00)$ & 0.00 & $0.000 * * *$ \\
\hline \multirow[t]{3}{*}{ D. S. Divisions } & Manmunai West & $1.09(0.69)$ & 0.08 & 0.90 \\
\hline & Eravurpattu & $1.98(0.54)$ & 0.68 & 0.21 \\
\hline & Korelapattu & & $0^{\mathrm{b}}$ & \\
\hline \multirow[t]{3}{*}{ Religion } & Hindu & $1466668.24(0.84)$ & 14.19 & $0.000^{* * * *}$ \\
\hline & Islam & $4759383.52(1.16)$ & 15.37 & $0.000^{* * *}$ \\
\hline & Other religion & & $0^{\mathrm{b}}$ & \\
\hline Constant & & & & \\
\hline
\end{tabular}


a. The reference category is: Food Insecure.

*Significant at 0.1 level

b. this parameter is set to zero because it is redundant

** Significant at 0.05 level

$* * *$ Significant at 0.01 level

\section{CONCLUSION AND POLICY RECOM- MENDATIONS}

While food security is a cross-cutting and multifaceted phenomenon, the results revealed that $48.7 \%$ of the paddy farming households were in moderate food security condition, $21.3 \%$ of the households in food secure condition and the rest were in food insecure condition. Almost all the households adopted coping strategies as short-term measures during times of food shortages. Rely on less preferred and less expensive foods, limit portion size at meal times and Purchase foods on credit were common coping behaviors among households.

Multinomial logistic regression results revealed that family size, education level of the head of the household and total monthly income significantly influence the food security status of the household of paddy farmers. One unit increase in family size decreases the odds ratio to be food secure rather than food insecure by 0.66 . And an increase of Rs 1000.00 in monthly income of a household increases the chances to be food secure by one time.

Considering the diversity of coping strategies employed in the study area to compensate for food shortages, policy instruments should be designed to improve the income level coupled with proper education and thereby to improve the food security status among the rural household in Batticaloa district .

\section{REFERENCES}

Babatunde R, Omotesho O and Sholotan O 2007 Socio-economic characteristics and food security of farming households in Kwara State, North-Central Nigeria. Pakistan Journal of Nutrition. 6(1): 41- 58

Bashir MK Naeem and SAK. Niazi 2010 Rural and peri-urban food security: a case of district Faisalabad of Pakistan.
WASJ, 9: 403-41.

Bashir MK, Steven S and R Pandit 2012 The determinants of rural household food security in the Punjab, Pakistan: an econometric analysis. Working paper 1203, School of Agricultural and Resource Economics, University of Western Australia, Crawley, Australia.

Department of Agriculture 2013 Government of SriLanka (online). http:// www.agridept.gov.lk/index.php/en/ crop-recommendations/ 808

Ersado L 2001 Productivity and Land Enhancing Technologies in Northern Ethiopia: Health, Public Investments and Sequential Adoption. Dissertation Submitted to the Faculty of Virginia Polytechnic Institute and State University. FAOSTAT Database. Food and Agriculture Organization of the UN, Rome. http://faostat.fao.org.

FAO 1996 Rome Declaration on World Food Security and World Food Summit Plan of Action. World Food Summit 13-17 November 1996. Rome.

Grimes DA and Schulz KF 2008 Making sense of odds and odds ratio. American Journal of Obstetrics and Gynecology. 111: 423- 426

Jenny A L and Egal F 2002 Household food security and nutrition in mountain areas- an often forgotten story, October 2002 nutrition program service, FAOESNP

McCracken V and Brandt J 1987 Household Consumption of Food Away from Home: total expenditure and by type o $\mathrm{f}$ food facility. American Journal of Agricultural Economics, 69(3): 274284.

Maxwell S and Frankenberger T, eds. 1992 Household food security: concepts, indicators, and measurements: a technical review. New York, NY, USA and Rome, UNICEF and IFAD. 
Maxwell D Clement A Carol L Margaret AK Sawudatu Z and Grace Mary Lamptey 1999 Alternative food-security indicators: revisiting the frequency and severity of coping strategies. Food Policy 24(4): 411-429.

Maxwell D, Watkins B, Wheeler $\mathrm{R}$ and Collins G 2003 The coping strategies index: A tool for rapid measurement of household food security and impact of food aid programs in Humanitarian emergencies.

Monde N 2003 Household food security in rural areas of central Eastern Cape: The case of Guquka in Victoria East and Koloni in Middledrift districts. Ph.D. Thesis, Department of Agricultural economics, University of Fort Hare, Alice PP 263.

Redman B 1980 The impact of women's time allocation on expenditure for meals away from home and prepared foods. American Journal of Agricultural Economics 62: 234-237

Samaratunga PA 2011 Multiple Facets of Food (In) Security in Sri Lanka: An Input to Food Policy. Policy Options to Achieve Food Security in South Asia: pp.51- 76.

Sindhu RS, Kaur I and Vatta K 2008 Food and nutritional insecurity and its determinants in food surplus areas: the case study of Punjab state. Agricultural Economics Research Review 21: 9198.

Steward H Blisard N Byuyan S and Nayga R 2004 The demand for food from home: full-service or fast food. United States: Economic Research Service, US Department of Agriculture.

USAID 2010 Sudan food security outlookFamine early warring system network. August 2010. Available at www.fews.net/sudan
Von Braun J Buis H Kumar S Pandya-Lorch N 1992 Improving food security of the poor: concept, policy and programs. Washington: International Food Policy Research Institute.

World Food Programme 2009 Southern Africa's poorest go hungry as WFP runs short of funds. (Online). Available at: http://www.wfp.org/news/newsrelease/Southern-africas-poorest-gohungry-wfp-runs

WF, Emergency Food Security Assessment in Baticaloa Sri Lanka, April, 2009. 